\title{
EXPERIMENT OF GASIFICATION OF THE SYNTHETICALLY MIXED SAMPLE OF WASTE IN NITROGEN ATMOSPHERE
}

\author{
Marián LÁZÁR*, Natália JASMINSKÁ*, Marta LENGYELOVÁ* \\ ${ }^{*}$ Faculty of Mechanical Engineering, Technical University of Košice, ul. Vysokoškolská 4, 04200 Košice, Slovak Republic
}

marian.lazar@tuke.sk, natalia.jasminska@tuke.sk, marta.lengyelova@tuke.sk

\begin{abstract}
The article presents results of gasification of the synthetically mixed sample of waste in a $30 \mathrm{kVA}$ transferred DC plasma reactor with a hollow graphite electrode. The subject of the research is a sample of waste consisting of components normally found in a municipal waste. The experimental test of waste gasification with a high level of organic fraction was implemented due to the verification of previously mentioned technology application also in the area of waste disposal at the current construction design of the reactor. Gasification took place in the inert atmosphere at the average temperature of $1578{ }^{\circ} \mathrm{C}$. The goal of the experiment was the verification of possible synthesis gas production applicable in the energetic applications and focus of the possible usage of the energetic potential of, up to now not often used, secondary energy sources such as wastes.
\end{abstract}

Key words: Plasma Reactor, Gasification, Organic Waste, Syngas

\section{INTRODUCTION}

One of the main problems of the countries in economical development is the processing and disposal of constantly growing amount of wastes. This problem is demonstrated especially in the countries where the population density reaches a high level (e.g. Japan) and spaces for the landfilling of waste are limited. Landfilling is currently the most known and at the same time the cheapest way in the area of mixed waste disposal. It plays a dominant role in the waste management in various countries all over the world. Disadvantages of this simple method of waste disposal lie in ground water and soil pollution, creation of malodor and nevertheless it destroys the country landscape. All the toxic matters contained in the waste remain in an unknown and uncontrolled form inside of the landfills. Realizing the environmental problems connected with the mixed waste landfilling, at present, the vast majority of states worldwide limit possibilities of waste landfilling through various laws and support the development of new technologies (Koukouzas et.al., 2008; Horbaj et.al., 2000).

The latter tendency in the area of thermal processing of various types of waste is their processing by a plasma technology. Waste disposal represents a complex process containing many physical and chemical interactions at the average temperature higher than $1000{ }^{\circ} \mathrm{C}$. The average operating temperature in the plasma reactor is affected by the characteristics of the processed waste, by the requirements for the output products from the process, by the type of the reactor used and so on (Arena, 2012). Gasification has several potential benefits over traditional combustion of solid waste, mainly related to the possibility of combining the operating conditions to obtain a syngas suitable for use in different applications (Arena, 2012).

Over the recent years several studies have been conducted to determine whether thermal plasma processes can be used for the gasification of waste with a high level of organic fraction. In many cases the results show a real possibility of using the plasma technology in the area of waste disposal (Gomez et.al., 2009; Shibaike et.al., 2005; Tanigaki et.al., 2012; Hrabovský, 2011; Consonni, et.al., 2012).

\section{TECHNOLOGY DESCRIPTION}

The experiment of gasification of the synthetically mixed sample of waste was carried out in a $30 \mathrm{kVA}$ transferred DC plasma reactor with a hollow graphite electrode. The heat necessary for the destruction of waste is ensured by a plasma arch generated between the hollow graphite electrode (cathode) and furnace hearth (anode). In most of the cases nitrogen or the air is used as gas necessary to create the plasma arch, which is transformed into the plasma state under the influence of electric field at high intensity. The simplified 3D model of plasma gasification technology is shown in Fig. 1.

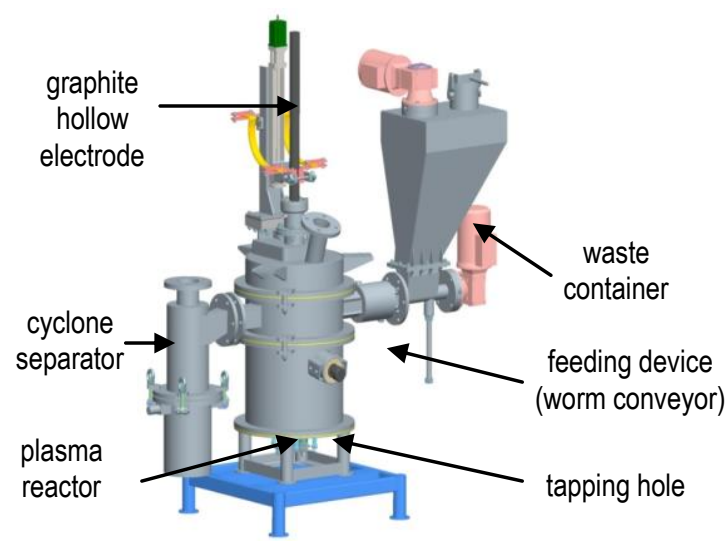

Fig. 1. 3D scheme of $30 \mathrm{kVA}$ plasma reactor

The graphite furnace hearth (anode) placed on the bottom of the reactor is protected by a layer of pure copper within every 
gasification experiment. Reactor shell is cooled down by the surrounding air. The synthetically mixed sample of waste entering the reactor is modified to granularity lower than $5 \mathrm{~mm}$ due to constructional reasons as well as better effectivity of the gasification process (Imriš, 2006).

\section{THE EXPERIMENT OF GASIFICATION}

In the experimental test a possibility of synthetically mixed sample of waste gasification was examined. The sample of waste consisted of five components, i.e. paper, plastics, biological waste, textile and glass. The percentage of the individual compound components in the mixture of waste sample is shown in Fig. 2. The basic physical characteristics, elemental analysis and the number of moles contained in the individual compound components, for $100 \mathrm{~g}$ of synthetically mixed sample of waste is shown in Tab. 1.

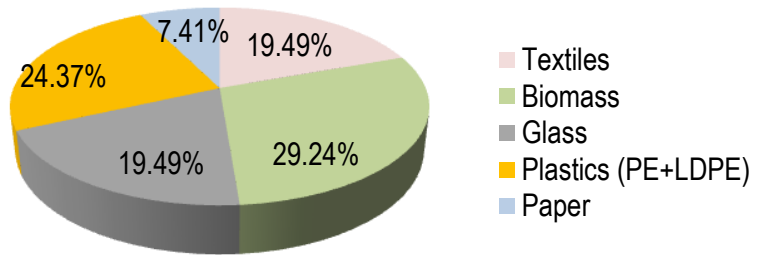

Fig. 2. The percentage of the individual compound components in the charge

Feeding of the charge of waste to the plasma reactor reaction chamber was provided by a tangential feeding device (worm conveyor) with a possibility of continuous waste feeding with granularity $<5 \mathrm{~mm}$. The continuous feeding was in progress in a two-second interval followed by a 28 -second pause. This process was cyclically repeated until the moment of total emptying of the waste container.

The gasification process was realized in a reduction atmosphere at nitrogen flowing via cathode $0.00981 \mathrm{m3} \cdot \mathrm{min}-1$. The total nitrogen capacity used for sealing the filling around the cathode and for avoiding the breakaway of the syngas via the waste container was at the level of $0.00669 \mathrm{~m} 3 \cdot \mathrm{min}-1$. Plasma arch generated between a hollow graphite electrodes (cathode), placed in a centrical way in the plasma reactor and a graphite furnace hearth which creates the bottom of the reactor (anode), maintain the temperature in the reactor chamber on the required level. The syngas produced is taken away using an aperture for a syngas exiting from the top of the reactor, directed to a cyclone separator which creates the first level of the syngas cleaning circuit. The operating parameters of gasification characterizing the gasification process of the synthetically mixed sample of waste are listed in Tab. 2.

Tab. 2. Operating parameters of the synthetically mixed sample of waste gasification

\begin{tabular}{|l|c|c|c|}
\hline \multirow{2}{*}{$\begin{array}{l}\text { Operating } \\
\text { parameters }\end{array}$} & Unit & $\begin{array}{c}|c| \\
\text { Calculation } \\
\text { based on the } \\
\text { parameters of } \\
\text { worm conveyor }\end{array}$ & $\begin{array}{c}\text { Experimental } \\
\text { measurement }\end{array}$ \\
\hline $\begin{array}{l}\text { Average } \\
\text { temperature }\end{array}$ & ${ }^{\circ} \mathrm{C}$ & 1578 & 1578 \\
\hline $\begin{array}{l}\text { Total feeding } \\
\text { time }\end{array}$ & $\mathrm{min}$. & 21.6 & 20 \\
\hline Charge weight & $\mathrm{kg}$ & 5.130 & 5.130 \\
\hline Feeding speed & $\mathrm{kg} \cdot \mathrm{min}^{-1}$ & 0.2375 & 0.257 \\
\hline Nitrogen flow & $\mathrm{m}^{3} \cdot \mathrm{min}^{-1}$ & 0.0165 & 0.0165 \\
\hline $\begin{array}{l}\text { Total energy } \\
\text { expenditure }\end{array}$ & $\mathrm{kWh}$ & 16.4 & 15.2 \\
\hline $\begin{array}{l}\text { Specific energy } \\
\text { expenditure }\end{array}$ & ${\mathrm{kWh} \cdot \mathrm{kg}^{-1}}^{\text {Syngas }}$ & 3.197 & 2.963 \\
\hline production & $\mathrm{m}^{3} \cdot \mathrm{kg}^{-1}$ & 1.069 & 1.018 \\
\hline
\end{tabular}

Total feeding time in case of the experimental measurement was estimated on the basis of a visual control of the waste container filling level and on the basis of calculation which was based on the waste container constructional dimensions, number of revolutions and a set feeding interval.

In the course of the experiment there were 3 syngas sample takings carried out, in the $6^{\text {th }}, 17^{\text {th }}$ and $29^{\text {th }}$ minute from the beginning of the charge (waste) feeding. The third syngas sample was taken right after the end of the feeding process. The analyzed syngas results are shown in the Table 3 .

While taking the individual syngas samples there was a high concentration of non-reacted carbon particulates contained in the gas. The total volume impurities in the syngas, captured in a cyclonic separator was at the level of $1.1 \mathrm{~kg}$ which represents approximately $21.5 \mathrm{wt}$ \% of the charge weight. Vitrificated slag tapping was not carried out after the experiment due to a low volume of charge.

The theoretical value of the emerging syngas volume in the gasification process was set on the basis of carbon balance. At the calculations, the basis was the elemental analysis of charge (synthetically mixed waste) considering oxidation of the total carbon content in the waste.

Assumed syngas production (based on the $C$ balance), being created by oxidation of $100 \%$ carbon containing in the charge and considering percentage proportion of the individual syngas components corresponding to the taken samples, was set to the interval 1.66 to $1.87 \mathrm{~m}^{3} \cdot \mathrm{kg}^{-1}$ (Tanigaki et.al., 2012; Lázár, 2012).

Tab. 1. Elemental analysis of charge

\begin{tabular}{|c|c|c|c|c|c|c|c|c|c|c|}
\hline \multirow[b]{2}{*}{ Sample Type } & \multicolumn{4}{|c|}{ Physical characteristics } & \multicolumn{6}{|c|}{ Elemental analysis (in a dry residue) } \\
\hline & $\begin{array}{l}W \\
(\%)\end{array}$ & $\begin{array}{c}A \\
(\%)\end{array}$ & $\begin{array}{l}H^{*} \\
(\%)\end{array}$ & $\begin{array}{c}Q_{\mathrm{s}} \\
\mathrm{MJ} \cdot \mathrm{kg}^{-1}\end{array}$ & $\begin{array}{c}C \\
(\%)\end{array}$ & $\begin{array}{c}H \\
(\%)\end{array}$ & $\begin{array}{c}N \\
(\%)\end{array}$ & $\begin{array}{c}0 \\
(\%)\end{array}$ & $\begin{array}{c}S \\
(\%)\end{array}$ & $\begin{array}{l}\mathrm{Cl} \\
(\%)\end{array}$ \\
\hline Sample of waste & 8.51 & 27.70 & 63.79 & 20.063 & 45.20 & 5.97 & 3.67 & 20.62 & 4.44E-03 & -- \\
\hline Mole number $\left[\mathrm{mol} \cdot(100 \mathrm{~g})^{-1}\right]$ & 0.47 & -- & -- & -- & 3.76 & 5.92 & 0.26 & 1.29 & 1.39E-04 & -- \\
\hline
\end{tabular}


Tab. 3. Results of the chromatographic analysis of syngas obtained by gasification of the synthetically mixed sample of waste

\begin{tabular}{|l|c|c|c|}
\hline \multirow{2}{*}{ Analysis type } & \multicolumn{3}{|c|}{ Chromatographic analysis } \\
\cline { 2 - 4 } & $\begin{array}{c}\text { sample 1 } \\
(\text { vol. \%) }\end{array}$ & $\begin{array}{c}\text { sample 2 } \\
(\text { vol. \%) }\end{array}$ & $\begin{array}{c}\text { sample 3 } \\
(\text { vol. \%) }\end{array}$ \\
\hline Methane $\left(\mathrm{CH}_{4}\right)$ & 8.59 & 4.77 & 2.54 \\
\hline Hydrogen $\left(\mathrm{H}_{2}\right)$ & 44.5 & 48.9 & 30.3 \\
\hline Oxygen $\left(\mathrm{O}_{2}\right)$ & 0.16 & 0.11 & 0.74 \\
\hline Nitrogen $\left(\mathrm{N}_{2}\right)$ & 6.03 & 6.61 & 15.9 \\
\hline Carbon dioxide $\left(\mathrm{CO}_{2}\right)$ & 6.60 & 1.66 & 2.42 \\
\hline Carbon monoxide $(\mathrm{CO})$ & 32.5 & 37.1 & 47.3 \\
\hline Ethene $\left(\mathrm{C}_{2} \mathrm{H}_{4}\right)$ & 0.97 & 0.49 & 0.52 \\
\hline Ethane $\left(\mathrm{C}_{2} \mathrm{H}_{6}\right)$ & 0.055 & 0.031 & 0.023 \\
\hline Ethine $\left(\mathrm{C}_{2} \mathrm{H}_{2}\right)$ & 0.42 & 0.24 & 0.15 \\
\hline $\begin{array}{l}\text { sum } \mathrm{C}_{3} \text { of } \\
\text { hydrocarbons }\end{array}$ & 0.011 & 0.004 & 0.004 \\
\hline $\begin{array}{l}\text { sum } \mathrm{C}_{4} \text { of } \\
\text { hydrocarbons }\end{array}$ & 0.0099 & 0.004 & 0.005 \\
\hline $\begin{array}{l}\text { sum } \mathrm{C}_{5-8} \text { of } \\
\text { hydrocarbons }\end{array}$ & 0.17 & 0.12 & 0.09 \\
\hline Heat value & $\begin{array}{c}13.12 \\
\mathrm{MJ} \cdot \mathrm{m}^{-3}\end{array}$ & $\begin{array}{c}12.31 \\
\mathrm{MJ} \cdot \mathrm{m}^{-3}\end{array}$ & $\begin{array}{c}10.71 \\
\mathrm{MJ} \cdot \mathrm{m}^{-3}\end{array}$ \\
\hline
\end{tabular}

\section{MODELING THE COMPOSITION OF THE SYNGAS BEING CREATED USING BOUNDARY EXPERIMENTAL CONDITIONS}

Experimentally obtained results were verified in the simulating program HSC Chemistry. Syngas values, generated by the program and based on the heat dependence are shown in Fig. 3.

As apparent from the Fig. 3 at temperatures over $1000^{\circ} \mathrm{C}$, the main syngas parts are hydrogen and carbon monoxide. Percentage representation of these elements, considering the temperature of approximately $1600{ }^{\circ} \mathrm{C}$, ideal gasification conditions and thermodynamic balance, are within hydrogen 61.89 vol. \% and carbon monoxide 31.84 vol. \%. However, the above mentioned values of a percentage proportion of $\mathrm{H} 2$ and $\mathrm{CO}$ do not contain nitrogen volume transported to the reaction chamber. Considering the inserted nitrogen to the reaction chamber with a volume of $16.5 \mathrm{I} \cdot \mathrm{min}-1$, there will be a decrease in the volume proportion of hydrogen and carbon monoxide in the generated syngas ( $\mathrm{H} 2$ around $58.18 \mathrm{vol}$. \%, $\mathrm{CO}$ around 29.93 vol. \%).

The oxygen deficiency in the reaction chamber of the plasma reactor causes the evasion of carbon particulates from reactor reaction chamber. The formation of the unreacted carbon is shown in Fig. 3 by the blue chart curve. According to a software generated data, the assumption of carbon particulates formation in the quantity of $23.9 \mathrm{~kg}$ to $100 \mathrm{~kg}$ of charge. This value represents approximately 24 wt. \% of the charge weight and it confirms the production of a high amount of carbon particulates, as observed during the experiment.

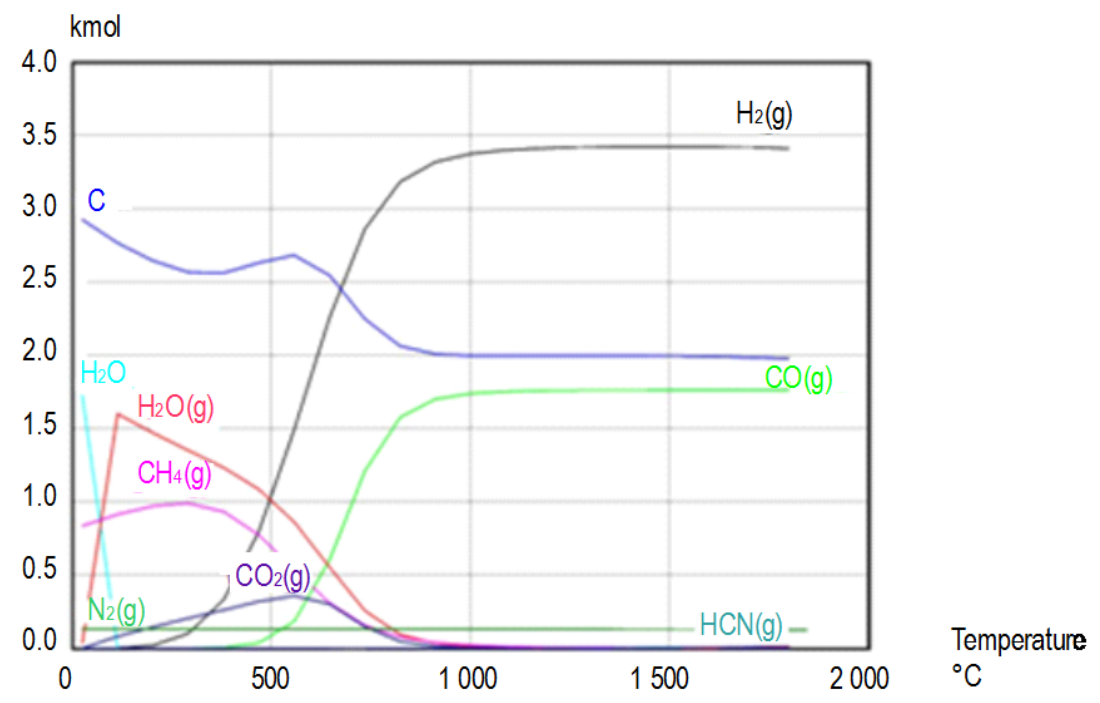

Fig. 3. Assumed syngas composition (generated by HSC Chemistry software)

\section{THE EXPERIMENT OF GASIFICATION}

Gasification of synthetically mixed sample of waste with a significant share of organic fraction was carried out in order to verify the plasma technology efficiency in the area of waste disposal and syngas production usable in energetic applications. Solid products of the plasma gasification, being created within the waste gasification experiment in the form of slag, non-reacted carbon particulates and fly ashes were only partially analyzed. At the suggested combustion temperature $\left(1600^{\circ} \mathrm{C}\right)$ it is assumed that the complex waste molecules are decomposed to simple molecules and the organic share of charge is transformed to gas components.

Observing the results of the first two syngas analyses (sample taking in the course of feeding) it is possible to record an increase of percentage volume values of $\mathrm{H}_{2}$ a $\mathrm{CO}$ in the second sample and decrease of shares of methane, carbon dioxide and higher hydrocarbons. This phenomenon may be caused by slower charge decomposition in the gasification chamber of the plasma reactor (compared to the starting part of gasification), while methane is generated in the process is partially decomposed into carbon and hydrogen. Out of the third sample analysis there is an increase in the percentage of nitrogen in the syngas seen as well 
as decrease in volume of many other compounds creating the gas mixture. The results of the third analysis confirm the presence of a higher charge content in the reaction chamber also after the end of the feeding process.

The volume of the syngas being produced (during the feeding) represents value around $1 \mathrm{~m}^{3} \cdot \mathrm{kg}^{-1}$ of the charge. Syngas production at the volume of $1 \mathrm{~m}^{3} \cdot \mathrm{kg}^{-1}$ of the charge considering the volume of non-reacted carbon in the form of fine particulates and syngas production also after the feeding process confirm applicability of the plasma technology also in the area of waste treating with a high share of organic fraction (from the technological point of view). The total volume of the two most important syngas components is at a remarkable level. The percentage share of hydrogen in syngas is between the intervals of $44-49 \mathrm{vol}$. \% during feeding process. Carbon monoxide is represented in the interval of $32-37$ vol. $\%$.

In the overall assessment of the experiment of waste gasification with a significant share of organic fraction, it is possible to add that in the gasification of waste in a reducing condition, formation of non-reacted carbon particulates is notable due to high disproportion in carbon and oxide atoms present in the waste. Nonreacted carbon particulates formation was confirmed by the results from simulation of the synthetically mixed waste sample gasification as well as by the experiment.

Principally, it is possible to make use of the total volume of carbon and hydrogen atoms present in waste for syngas production at a sufficiently high temperature and sufficient number of oxidizer added into the reaction chamber of the plasma reactor. Maximum conversion of the organic part of the waste to syngas is obtained by a total carbon oxidation to carbon monoxide. Due to deficiency of oxygen atoms in the reaction chamber, compared to carbon atoms present in the majority of the materials of organic origin, there is an oxidizer added into the gasification process in a gas or liquid phase (Hrabovský, 2011). Based on the foreign literature, within biomass gasification in the air atmosphere, the ideal ratio between the oxygen volume in the oxidation process of thermal waste disposal and the oxygen volume necessary for a complex stoichiometric oxidation lies in the interval of 0,25 0,35 . The presented ratio is very likely to be applicable also in waste gasification with a high share of organic fraction.

\section{CONCLUSION}

Gasification of municipal solid waste (MSW) and biomass as an energy recovery method has been widely researched all over the world (Tanigaki et.al., 2012, Blejchař et. al., 2007). There was confirmed the substantiality of plasma waste gasification with a high percentage of organic fraction in a $30 \mathrm{kVA}$ plasma reactor. The chromatographic analysis results of the taken syngas samples show high level of the two most important combustible syngas parts, i.e. $\mathrm{CO}$ a $\mathrm{H}_{2}$, which are applicable in energetic production systems. The representation of the $\mathrm{CO}$ and $\mathrm{H} 2$ elements in the syngas is at the level of $76-86 \mathrm{vol}$. \%. The heat value in the gasification process of the generated gas is in the interval of $10.7-13.12 \mathrm{MJ} \cdot \mathrm{m}^{-3}$.

Taking into consideration the results of the implemented ex- periment, focused on the syngas production applicable in energetic applications, plasma gasification represents a possible alternative also in the area of a common municipal waste disposal. Possibility to destroy organic and toxic matters contained in the municipal waste as well as the usage the chemical energy storage in the waste raise a question of starting a serious broad research in the particular area of waste disposal. However, optimization of the boundary gasification conditions and the construction adjustments of the reactor from the point of view of more effective syngas production are necessary. Higher gasification process effectivity lies, first of all, in solving the transportation of the oxidizer between the elements of the treated charge with a significant percentage of the organic fraction and in decreasing the energy consumption related to a $\mathrm{kg}$ of charge.

\section{REFERENCES}

1. Arena U. (2012), Process and technological aspects of municipal solid waste gasification. A review, Waste Management, Vol. 32, 625-639.

2. Blejchař T., Čech B., Malý R., Kolat P., Dluhoš M. (2007), Plazmové systémy v energetice In: Environmental Protection into the Future, Czestochowa University of Technology, 30-42.

3. Consonni S., Vigano F. (2012), Waste gasification vs. conventional Waste-To-Energy: A comparative evaluation of two commercial Technologies, Waste Management,Vol. 32, 653-666.

4. Gomez E., Rani A. D., Cheeseman R. C., Deegan D., Wise M., Boccaccini R. A. (2009), Thermal plasma technology for the treatment of wastes, Journal of Hazardous Materials, Vol. 161, 614-626.

5. Horbaj P., Imriš I. (2000), Some possibilities of municipal waste treating (Niektoré možnosti využívania komunálneho odpadu), International Conference TOP 2000, Častá Papiernička 15-16 jún 2000, 233-243.

6. Hrabovský M. (2011), Thermal Plasma Gasification of Biomass, Biomass and Bioenergy, 39-62, ISBN 978-953-307-491-7.

7. Imriš I. (2006), Plasma reactor for waste treatment, Heat transfer and renewable sources of energy Szczecin, Wydawnictwo Uczelniane Politechniki Szczecinskiej, 301-308.

8. Internal Material of company "Silvergas s.r.o."

9. Koukouzas N., Katsiadakis A., Karlopoulos E., Kakaras E. (2008), Co-gasification of solid waste and lignite - A case study for Western Macedonia, Waste Management, Vol. 28, 1263-2675.

10. Lázár M. (2012), Research of municipal waste utilization possibilities in the plasma reactor, Doktorant thesis, Technical University of Košice.

11. Shibaike, H., et. al. (2005), Development of high-performance direct melting process for municipal solid waste, Nippon Steel Technical Report [online]

12. Tanigaki N., Manako K., Osada M. (2012), Co-gasification of municipal solid waste and material recovery in a large-scale gasification and melting system, Waste Management, Vol. 32, 667-675.

The work has been accomplished under the research project No. ITMS 26220220044 financed by the Agency of the Ministry of Education of The Slovak Republic from the Structural Funds of EU Operational Programme "Research and Development". 